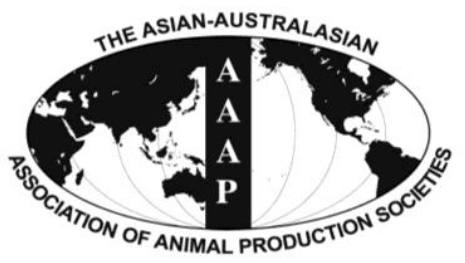

Asian Australas. J. Anim. Sci.

Vol. 26, No. 8 : 1127-1136 August 2013

http://dx.doi.org/10.5713/ajas.2013.13013

www.ajas.info

pISSN 1011-2367 elSSN 1976-5517

\title{
Effects of Plant Herb Combination Supplementation on Rumen Fermentation and Nutrient Digestibility in Beef Cattle
}

\author{
M. Wanapat*, S. Kang, P. Khejornsart, and S. Wanapat ${ }^{1}$ \\ Tropical Feed Resources Research and Development Center (TROFREC), Department of Animal Science, \\ Faculty of Agriculture, Khon Kaen University, Khon Kaen 40002, Thailand
}

\begin{abstract}
Four rumen-fistulated crossbred beef cattle (Brahman native) were randomly assigned according to a $4 \times 4$ Latin square design experiment to be fed plant herb supplements in their concentrate mixture. The treatments were: without herb supplementation (Control), lemongrass meal supplementation at $100 \mathrm{~g} / \mathrm{d}(\mathrm{L})$, lemongrass meal supplementation at $100 \mathrm{~g} / \mathrm{d}$ plus peppermint powder at 10 $\mathrm{g} / \mathrm{d}$ (LP), and lemongrass meal supplementation at $100 \mathrm{~g} / \mathrm{d}$ plus peppermint powder at $10 \mathrm{~g} / \mathrm{d}$ with garlic powder $40 \mathrm{~g} / \mathrm{d}$ (LPG), respectively. Based on the present study, the DMI and apparent digestibility of DM, OM, aNDF and ADF were not affected by dietary herb supplementation while $\mathrm{CP}$ digestibility tended to be decreased by herb supplement. Moreover, $\mathrm{NH}_{3}-\mathrm{N}$ and $\mathrm{BUN}$ were decreased in all herb supplemented treatments and there was a tendency to an increase in ruminal $\mathrm{pH}$ in all herb supplemented groups. While there was no change in TVFA and C4 among lemongrass treatments, C2 was decreased in all herb supplemented treatments while C3 was increased. Methane production by calculation was the lowest in the LP and LPG groups. Population sizes of bacteria and protozoa were decreased in all herb supplemented groups, but not fungal zoospores. In all supplemented groups, total viable and proteolytic bacteria were decreased, while amylolytic and cellulolytic bacteria were similar. More importantly, in all herb supplemented groups, there were higher $\mathrm{N}$ balances, while there was no difference among treatments on purine derivative (PD) excretion or microbial $\mathrm{N}$. Based on the results above, it could be concluded that there was no negative effect on ruminal fermentation characteristics and nutrient utilization by plant herb supplement, but protozoal population and $\mathrm{CH}_{4}$ production were reduced. Thus, lemongrass alone or in combination with peppermint and garlic powder could be used as feed additives to improve rumen fermentation efficiency. (Key Words: Herb, Lemongrass, Garlic, Peppermint, Ruminal Fermentation, Methane)
\end{abstract}

\section{INTRODUCTION}

Animal nutritionists have been attempting to manipulate rumen fermentation not only in order to improve fibre digestibility, but also to reduce $\mathrm{CH}_{4}$ emissions and $\mathrm{N}$ excretion (Patra et al., 2006). It was reported that the use of synthetic antibiotics as feed additives have been proven to be a useful way in reducing energy and $\mathrm{N}$ losses in ruminants (McGuffey et al., 2001). However, antibiotic feed additives have caused public concern due to the potential of residues in milk and meat production. Since synthetic antibiotics as feed additives were banned by the European Union in 2002 (Russell and Houlihan, 2003), scientists have been interested in evaluating the potential of natural

\footnotetext{
* Corresponding Author: M. Wanapat. Tel: +66-4320-2368, Fax: +66-4320-2368, E-mail: metha@kku.ac.th

${ }^{1}$ Department of Plant Science and Natural Resources, Faculty of Agriculture, Khon Kaen University, Khon Kaen, 40002, Thailand. Submitted Jan. 6, 2013; Accepted Mar. 27, 2013; Revised Apr. 23, 2013
}

antimicrobials, such as herbs and plant extracts, which have been used for centuries for various purposes in human diets. These plant or herb extracts (garlic oil or lemongrass powder) have been shown to manipulate ruminal fermentation and improve nutrient utilization in ruminants (Busquet et al., 2005; Patra et al., 2006; Wanapat et al., 2008a).

Plant herbs such as garlic (Allium sativum), lemongrass (Cymbopogon citrates, DC. Stapf.) and peppermint (Mentha xpiperita) are widely used as antibacterial agents and extensively used to maintain the microbial ecosystem of the gastrointestinal tract especially in tropical regions. Garlic has been studied as aqueous or ethanol extracts or as a dried powder (Shin and Kim, 2004) as it contains a high level of organosulfur compounds such as allicin, ajoene, S-allylcysteine, diallyl disulfide, S-methylcysteine sulfoxide and S-allylcysteine (Chi et al., 1982). Studies with garlic as an alternative growth promoter in livestock production reported improved growth rate, digestibility and carcass 
traits (Bampidsis et al., 2005; Tatara et al., 2008; Kongmun et al., 2011). Lemongrass and peppermint have been reported as feed additives to improve production performance of beef and dairy cattle (Busquet et al., 2005; Hosoda et al., 2005; Yang et al., 2007) and to enhance rumen fermentation efficiency (Wanapat et al., 2008a; b; Kongmun et al., 2010). Nevertheless, there is little information on effect of garlic, lemongrass or peppermint in combination as feed additives on rumen microbial fermentation and ecology.

Therefore, the aim of this study was to evaluate supplementation of these herb combinations on feed intake, digestibility, rumen fermentation and urinary purine derivative excretion using crossbred beef cattle fed rice straw.

\section{MATERIALS AND METHODS}

\section{Experimental design, diets and animals management}

Four rumen fistulated crossbred beef cattle of $434 \pm 48$ $\mathrm{kg}$ body weight (BW) were randomly assigned to a $4 \times 4$ Latin square design experiment to receive one of four of dietary treatments as: without herb (Control), lemongrass meal supplementation at $100 \mathrm{~g} / \mathrm{d}(\mathrm{L})$, lemongrass meal supplementation at $100 \mathrm{~g} / \mathrm{d}$ plus peppermint powder at 10 $\mathrm{g} / \mathrm{d}$ (LP), and lemongrass meal supplementation at $100 \mathrm{~g} / \mathrm{d}$ plus peppermint powder at $10 \mathrm{~g} / \mathrm{d}$ and garlic powder at 40 $\mathrm{g} / \mathrm{d}$ (LPG). All herbs used in this experiment were the variety from Sisaket province, Thailand. Garlic powder was prepared using Chinese garlic (Kratium Jin, Thai language), harvested at the age of $120 \mathrm{~d}$ after planting, while lemongrass was harvested at $90 \mathrm{~d}$. Raw garlic and lemongrass were chopped, sun-dried, milled through screen of $0.5 \mathrm{~cm}$ and then oven dried at $50^{\circ} \mathrm{C}$ before grinding through a $1 \mathrm{~mm}$ screen. Peppermint (Kitchen mint, Melissa officinalis) was sun-dried and ground through a $1 \mathrm{~mm}$ screen. All herds were planted on farm, collected and prepared for the entire experiment in advance.

All cattle were housed in individual pens $(3 \times 5 \mathrm{~m})$ and fed concentrate at $5 \mathrm{~g} / \mathrm{kg} \mathrm{BW}$ with urea treated rice straw (UTRS) fed ad libitum twice daily at 06:00 and 14:00 h. The UTRS was prepared by adding $5 \mathrm{~kg}$ of urea in $100 \mathrm{~L}$ of water which was poured over to $100 \mathrm{~kg}$ of air dry rice straw, sprayed onto a stack of 5 rice straw bales (approximately 20 $\mathrm{kg} / \mathrm{bale}$ ) and then covered with a plastic sheet for a minimum of $10 \mathrm{~d}$ before feeding (Wanapat et al., 2009).

Fresh clean water and mineral blocks (Table 1) were available at all time. Intake of concentrate and rice straw were measured separately and refusals were recorded daily. The experiment was conducted for four periods and each of the four periods lasted for $21 \mathrm{~d}$ in length, with the first $14 \mathrm{~d}$ as feed adaptation and intake measurement, while the last 7 $\mathrm{d}$ for sample collection as animals were moved to metabolism crates for total collection method.

\section{Data collection and sampling procedures}

Feed samples were collected twice a week for DM analysis. During the last $7 \mathrm{~d}$ of each period, samples of the concentrate mixture, UTRS, refusals, feces and urine were collected daily. Each of the feed samples during the collection days were pooled by period while feces and urine samples were pooled by each animal in each period and

Table 1. Ingredients and chemical compositions of the concentrate, urea treated rice straw, garlic powder, peppermint powder and lemongrass meals

\begin{tabular}{|c|c|c|c|c|c|}
\hline & Concentrate & UTRS $^{\mathrm{a}}$ & $\mathrm{G}^{\mathrm{b}}$ & $\mathrm{L}^{\mathrm{c}}$ & $\mathrm{P}^{\mathrm{d}}$ \\
\hline \multicolumn{6}{|l|}{ Ingredients (g/kg DM) } \\
\hline Cassava chip & 710 & & & & \\
\hline Rice bran & 90 & & & & \\
\hline Coconut meal & 50 & & & & \\
\hline Palm kernel meal & 50 & & & & \\
\hline Sulphur & 10 & & & & \\
\hline Mineral mixture & 10 & & & & \\
\hline Molasses & 40 & & & & \\
\hline Urea & 30 & & & & \\
\hline Salt & 10 & & & & \\
\hline \multicolumn{6}{|c|}{ Chemical compositions (g/kg DM) } \\
\hline Dry matter $(\mathrm{g} / \mathrm{kg})$ & 940 & 554 & 932 & 927 & 924 \\
\hline Organic matter & 827 & 872 & 964 & 867 & 875 \\
\hline Crude protein & 141 & 74 & 180 & 14 & 12 \\
\hline Neutral detergent fibre & 198 & 716 & 69 & 650 & 33 \\
\hline Acid detergent fibre & 84 & 526 & 52 & 427 & 173 \\
\hline Ether extract & 26 & 3 & 14 & 16 & 12 \\
\hline Essential oil & - & - & 3.4 & 1.6 & 7.2 \\
\hline
\end{tabular}

${ }^{\mathrm{a}}$ Urea treated rice straw. ${ }^{\mathrm{b}}$ Garlic powder. ${ }^{\mathrm{c}}$ Lemongrass meal. ${ }^{\mathrm{d}}$ Peppermint powder. 
stored at $-20^{\circ} \mathrm{C}$ for later chemical analyses. All samples were divided into two parts, which the first was for DM analyses, while the second was kept for analyses of ash, CP, $\mathrm{EE}$, aNDF and ADF. Urine samples were analyzed for total $\mathrm{N}$ and allantoin concentrations.

At the end of each period, rumen fluid was collected at $0,2,4$ and $6 \mathrm{~h}$ post feeding. Approximate $200 \mathrm{ml}$ of rumen fluid were taken from the middle part of the rumen using a $60 \mathrm{ml}$ hand syringe connected to a tube. Rumen fluid was immediately measured for $\mathrm{pH}$ using a portable $\mathrm{pH}$ meter (HANNA instrument HI 8424 microcomputer, Singapore). Rumen fluid samples were filtrated through 4 layers of cheesecloth and subsamples were divided into 3 portions; the first $45 \mathrm{ml}$ was transferred to a plastic bottle to which 5 $\mathrm{ml}$ of $1 \mathrm{M} \mathrm{H}_{2} \mathrm{SO}_{4}$ had been added to stop microbial fermentation and then centrifuged at $3,000 \times \mathrm{g}$ for $10 \mathrm{~min}$. About $25 \mathrm{ml}$ of supernatant were collected and analyzed for $\mathrm{NH}_{3}-\mathrm{N}$ and total VFA (TVFA). The second portion was 1 $\mathrm{ml}$ of rumen fluid which was transferred to a plastic bottle to which $9 \mathrm{ml}$ of $10 \mathrm{ml} / \mathrm{L}$ formalin solution (1:9 v/v, rumen fluid: $10 \mathrm{ml} / \mathrm{L}$ formalin) had been added and then stored at $4^{\circ} \mathrm{C}$ for measurement of bacteria, fungal zoospores and the protozoal population. The third portion $(10 \mathrm{ml})$ was used for viable bacteria count (cellulolytic, proteolytic, amylolytic and total viable bacteria).

A $10 \mathrm{ml}$ blood sample was drawn from the jugular vein at the same time as rumen fluid was collected. Blood samples were immediately placed on ice and transported to the laboratory and refrigerated at $4{ }^{\circ} \mathrm{C}$ for $1 \mathrm{~h}$. Blood plasma was separated from the whole blood by centrifuge at $3,500 \times \mathrm{g}$ for $20 \mathrm{~min}$. Plasma was collected and stored at $20^{\circ} \mathrm{C}$ for later blood urea $\mathrm{N}(\mathrm{BUN})$ analysis.

\section{Analytical procedures}

Feeds, refusals and fecal samples were dried at $60^{\circ} \mathrm{C}$ and ground through a $1 \mathrm{~mm}$ screen using a Cyclotech Mill, (Tecator, Sweden) and then analyzed using standard methods of AOAC (1995) for DM (ID 967.03), ash (ID 942.05) and EE (ID 954.02). Acid detergent fiber was determined according to the AOAC method (1995; ID 973.18) and expressed inclusive of residual ash. The aNDF was estimated according to Van Soest et al. (1991) with addition of $\alpha$-amylase, but without sodium sulphite, and the results were expressed with residual ash. Total $\mathrm{N}$ was determined according to AOAC (1995; ID 984.13).

Ruminal $\mathrm{NH}_{3}-\mathrm{N}$ concentration was analyzed by Kjeltech Auto 1030 Analyzer (AOAC, 1995; ID 973.18), while ruminal VFA production was analyzed using High Pressure Liquid Chromatography (HPLC, Water and Novapak model 600E; water mode 1484 UV detector; column novapak C18; column size $3.9 \mathrm{~mm} \times 300 \mathrm{~mm}$; mobile phase $10 \mathrm{mM} \mathrm{H} \mathrm{PO}_{4}(\mathrm{pH} 2.5)$ ) according to Samuel et al. (1997). Rumen fluid was used for total direct counts of bacterial, protozoa and fungal zoospores using methods of Galyean (1989) by haemacytometer (Boeco, Singapore). The fluid sample was diluted using autoclave distilled water as a medium by 100,10 , and 10 times, and counted using $10 \times 40,10 \times 40$, and $10 \times 10$ ocular $\times$ objective of a microscope for bacteria fungal zoospores and protozoa, respectively, according to the method of Galyean (1989). Groups of bacteria (i.e., cellulolytic, proteolytic, amylolytic and total viable bacteria counts) were measured using the Hungate (1969) roll-tube technique. Total viable counts of bacteria were determined in roll tubes on a complete medium (Hobson, 1969), while numbers of cellulolytic bacteria were estimated as the most probable number using cellulose medium (Hobson, 1969). In addition, while the population of proteolytic bacteria were determined using casein medium, the population of amylolytic bacteria were estimated using starch medium (Hobson, 1969). Culture methods were based on those described by Hungate (1969). The blood urea nitrogen (BUN) was measured according to Crocker (1967).

During last $7 \mathrm{~d}$ of each period, urine was collected twice daily. To avoid $\mathrm{N}$ losses, urine was collected in a container acidified with $3 \mathrm{~mol} / \mathrm{L}$ sulphuric acid. Urinary allantoin was determined by HPLC (Chen et al., 1993). The amount of microbial purine absorbed was calculated from urinary purine derivative (PD) excretion according to Chen and Gomes (1995) as: $\mathrm{Y}=0.85 \mathrm{X}+0.385 \mathrm{BW}^{0.75}$.

The supply of microbial $\mathrm{N}$ was estimated as: Microbial $\mathrm{N}(\mathrm{MN})(\mathrm{g} / \mathrm{d})=\mathrm{X} \times 70 /(0.116 \times 0.83 \times 1,000)=0.727 \times \mathrm{X}$ where: $\mathrm{X}$ and $\mathrm{Y}$ are absorption and excretion of $\mathrm{PD}$ in $\mathrm{mmol} / \mathrm{d}$, respectively. Efficiency of microbial $\mathrm{N}$ synthesis (EMNS) was calculated as: EMNS = MN (g/d)/DOMR where: $\mathrm{DOMR}=$ apparently digested $\mathrm{OM}$ in the rumen $(650$ $\mathrm{g} / \mathrm{kg}$ digestible $\mathrm{OM}$ intake).

\section{Statistical analysis}

All data were analyzed according to a $4 \times 4$ Latin square design using the SAS (1996) GLM procedure according to the model: $\mathrm{Y}_{i j k}=\mu+\mathrm{M}_{i}+\mathrm{A}_{j}+\mathrm{P}_{k}+\varepsilon_{i j k}$; where: $\mathrm{Y}_{i j k}$, observation from cattle $j$, receiving diet $i$, in period $k ; \mu$, the overall mean; $\mathrm{M}_{i}$, effect of herbs supplementation $(i=1,2,3,4)$, $\mathrm{A}_{j}$, the effect of cattle $(j=1,2,3,4), \mathrm{P}_{k}$, the effect of period $(k=1,2,3,4)$, and $\varepsilon_{i j k}$ residual effect. Main effects of treatment, cattle and period were included in the model with the residual used as the error term. Results are presented as mean values with the standard error of the means. Orthogonal contrasts were used to compare treatment means of control verses supplemented groups and type of supplementation.

\section{RESULTS}

\section{Chemical composition of feed}

Experimental feed and their chemical compositions are shown in Table 1. The mixture of concentrate, consisting of 
Table 2. Influence of lemongrass, peppermint and garlic supplementation on ruminal $\mathrm{pH}$, blood urea $\mathrm{N}$ and rumen fermentation characteristics in cattle

\begin{tabular}{|c|c|c|c|c|c|c|c|c|}
\hline & \multicolumn{4}{|c|}{ Treatment $(\mathrm{g} / \mathrm{d})^{\mathrm{a}}$} & \multirow{2}{*}{ SEM } & \multicolumn{3}{|c|}{ Contrast $\mathrm{p}$} \\
\hline & $\mathrm{C}$ & $\mathrm{L}$ & LP & LPG & & $\mathrm{C}$ vs Sup ${ }^{\mathrm{b}}$ & L vs LP, LPG & LP vs LPG \\
\hline Ruminal pH & 6.54 & 6.73 & 6.81 & 6.90 & 0.08 & 0.06 & 0.13 & 0.96 \\
\hline $\mathrm{NH}_{3}-\mathrm{N}(\mathrm{mg} / \mathrm{dl})$ & 22.8 & 21.2 & 18.7 & 18.3 & 0.53 & 0.01 & 0.09 & 0.19 \\
\hline BUN (mg/dl) & 13.4 & 11.2 & 9.8 & 9.5 & 0.73 & 0.02 & 0.06 & 0.34 \\
\hline Total VFAs (mmol/L) & 109.1 & 105.0 & 102.0 & 101.9 & 2.47 & 0.51 & 0.99 & 0.76 \\
\hline \multicolumn{9}{|l|}{ VFA, mol/100 mol } \\
\hline Acetate $(\mathrm{C} 2)$ & 73.2 & 70.0 & 66.7 & 66.9 & 0.50 & 0.02 & 0.04 & 0.96 \\
\hline Propionate (C3) & 22.7 & 22.6 & 22.8 & 23.2 & 0.47 & 0.04 & 0.27 & 0.67 \\
\hline Butyrate (C4) & 13.2 & 12.4 & 12.4 & 11.7 & 0.28 & 0.33 & 0.95 & 0.75 \\
\hline $\mathrm{C} 2: \mathrm{C} 3$ ratio & 3.2 & 3.1 & 2.9 & 2.9 & 0.07 & 0.01 & 0.13 & 0.20 \\
\hline $\mathrm{CH}_{4}{ }^{\mathrm{c}}(\mathrm{ml} / 100 \mathrm{ml})$ & 29.3 & 28.8 & 28.1 & 27.9 & 0.33 & 0.04 & 0.05 & 0.18 \\
\hline
\end{tabular}

${ }^{\mathrm{a}} \mathrm{C}=$ Control; L = Lemongrass meal; LP = Lemongrass meal and peppermint powder; LPG = Lemongrass meal plus peppermint and garlic powder.

${ }^{\mathrm{b}}$ Supplemented diets. ${ }^{\mathrm{c}}$ Calculated according to Moss et al. $(2000)$ as: $\mathrm{CH}_{4}$ production $=0.45(\mathrm{C} 2)-0.275(\mathrm{C} 3)+0.4(\mathrm{C} 4)$.

available local feeds such as energy source (cassava chips), protein sources (rice bran, coconut meal and palm kernel meal) and non-protein $\mathrm{N}$ (urea), had a higher quality in terms of CP and were low in fiber $(141$ and $198 \mathrm{~g} / \mathrm{kg} \mathrm{DM}$, respectively). The mean $\mathrm{CP}$ level of $\mathrm{G}$ was the highest among all herbs followed by $\mathrm{L}$ and $\mathrm{P}(180,14$ and $12 \mathrm{~g} / \mathrm{kg}$ $\mathrm{DM}$, respectively). Meanwhile, both $\mathrm{G}$ and $\mathrm{L}$ contained a much higher level of aNDF as well as ADF when compared with P. However, there was a similarity of EE contained in all herbs. On the other hand, the nutritive value of rice straw was improved by urea treatment. The UTRS contained CP at $74 \mathrm{~g} / \mathrm{kg}$ and fiber fraction at 716 and $526 \mathrm{~g} / \mathrm{kg}$; aNDF and $\mathrm{ADF}$, respectively.

\section{Rumen fermentation and blood metabolites}

The effects of various herb supplementation in the concentrate diet on rumen fermentation and blood metabolites are presented in Table 2. The results showed that ruminal $\mathrm{pHs}$ were not affected by herb supplement and were at $\mathrm{pH}=6.5$ to 6.9 . However, there was a tendency to increase ruminal $\mathrm{pH}$ as animals were supplemented with herds $(p=0.06)$, especially in herb combination treatment
(LPG). On the other hand, ruminal $\mathrm{NH}_{3}-\mathrm{N}$ and $\mathrm{BUN}$ concentration were significantly decreased by herb supplements $(\mathrm{p}<0.05)$. All herb supplemented treatments $(\mathrm{L}$, LP and LPG) had lower concentrations of $\mathrm{NH}_{3}-\mathrm{N}$ and BUN (18.3 to 21.2 and 9.5 to $11.2 \mathrm{mg} / \mathrm{dl}$, respectively) than in the control treatment (22.8 and $13.4 \mathrm{mg} / \mathrm{dl}$, respectively). However, there was no difference among the three herb supplements on $\mathrm{NH}_{3}-\mathrm{N}$ and BUN. In this study, there were no significant differences ( $p>0.05)$ in total VFA and C4 concentration when animals were supplemented with and without herbs. In contrast, while C2 concentration was significantly decreased by herb supplementation $(\mathrm{p}=0.02)$, C3 concentration was slightly increased $(p=0.04)$. As a consequence, the $\mathrm{C} 2: \mathrm{C} 3$ ratio was decreased in herb supplementation. In addition, based on the calculation, methane production $\left(\mathrm{CH}_{4}\right)$ was lower in herb supplemented treatments as compared to control $(p=0.04)$ and tended to show the lowest value in the herb combination group (LPG $=27.9 \mathrm{ml} / 100 \mathrm{ml})(\mathrm{p}=0.05)$.

\section{Rumen microorganism population}

As shown in Table 3, bacterial and protozoal counts

Table 3. Effect of lemongrass, peppermint and garlic supplementation on populations of rumen microbes

\begin{tabular}{|c|c|c|c|c|c|c|c|c|}
\hline & \multicolumn{4}{|c|}{ Treatment $(\mathrm{g} / \mathrm{d})^{\mathrm{a}}$} & \multirow{2}{*}{ SEM } & \multicolumn{3}{|c|}{ Contrast $\mathrm{p}$} \\
\hline & $\mathrm{C}$ & $\mathrm{L}$ & LP & LPG & & C vs Sup ${ }^{b}$ & L vs LP, LPG & LP vs LPG \\
\hline \multicolumn{9}{|l|}{ Ruminal microbes $\times$ cell $/ \mathrm{ml}$} \\
\hline Bacteria, $\times 10^{11}$ & 7.6 & 7.2 & 3.8 & 3.1 & 1.13 & $<0.01$ & 0.06 & 0.10 \\
\hline Protozoa, $\times 10^{5}$ & 7.8 & 5.7 & 4.8 & 5.0 & 0.99 & 0.04 & 0.16 & 0.41 \\
\hline Fungal zoospores, $\times 10^{4}$ & 8.3 & 8.2 & 9.0 & 7.9 & 0.25 & 0.10 & 0.56 & 0.38 \\
\hline \multicolumn{9}{|l|}{ Viable bacteria (CFU/ml) } \\
\hline Total, $\times 10^{10}$ & 5.1 & 4.1 & 1.8 & 2.2 & 0.32 & 0.02 & 0.07 & 0.09 \\
\hline Amylolytic, $\times 10^{7}$ & 9.1 & 7.6 & 7.2 & 8.0 & 2.01 & 0.11 & 0.54 & 0.92 \\
\hline Proteolytic, $\times 10^{7}$ & 10.0 & 6.3 & 6.4 & 5.3 & 1.21 & $<0.01$ & 0.09 & 0.25 \\
\hline Cellulolytic, $\times 10^{8}$ & 3.8 & 2.0 & 4.2 & 3.7 & 0.78 & 0.10 & 0.62 & 0.73 \\
\hline
\end{tabular}

${ }^{\mathrm{a}} \mathrm{C}=$ Control; $\mathrm{L}=$ Lemongrass meal; $\mathrm{LP}=$ Lemongrass meal and peppermint powder; $\mathrm{LPG}=$ Lemongrass meal plus peppermint and garlic powder.

${ }^{\mathrm{b}}$ Supplemented diets. 
were found to be different $(\mathrm{p}<0.05)$ between all treatments while fungal zoospores were not affected by herb supplementation $(p>0.05)$. The treatments with herb supplementation had lower ruminal protozoal and bacterial populations than control. Moreover, viable total bacterial count and proteolytic bacteria were decreased by herb supplements $(p<0.05)$ while cellulolytic and amylolytic bacteria were similar among treatments $(p>0.05)$. The herb supplemented treatments were lower in total bacterial count and proteolytic bacteria as compared to the control treatment. The lowest values were observed in herb combination groups (LP and LPG). However, cellulolytic and amylolytic bacteria were not affected and ranged at 2.0$3.8 \times 10^{8}$ and $7.2-9.1 \times 10^{7}$ cell $/ \mathrm{ml}$, respectively.

\section{Feed intake and apparent nutrient digestibility}

Table 4 presents the data on daily feed intakes and nutrient digestibility as affected by herb supplementation. There was no significant difference among treatments on roughage and concentrate intake; thus resulting in a similarity of total feed intake $(p>0.05)$ and the values were stable at 7.1 to $7.5,2.1$ to 2.2 and 9.3 to $9.6 \mathrm{~kg} / \mathrm{d}$, respectively. Moreover, there were no significant differences in apparent digestibility of DM, OM, aNDF and ADF among treatments ( $>0.05)$ while CP digestibility was different $(\mathrm{p}<0.05)$. Digestibility of CP was the highest in the $\mathrm{L}$ supplemented treatment $(0.65 \mathrm{~kg} / \mathrm{kg})$ and the lowest was found in the LPG supplemented group $(0.53 \mathrm{~kg} / \mathrm{kg})$.

\section{Nitrogen utilization and purine derivatives}

There were no differences among all treatments on total $\mathrm{N}$ intake $(\mathrm{p}>0.05)$ and the values ranged from 133.7 to
$136.2 \mathrm{~g} / \mathrm{d}$ (Table 5). Moreover, fecal $\mathrm{N}$ was not affected by herb supplements while urinary $\mathrm{N}$ was decreased in herb supplemented groups, especially in the herb combination $(p<0.05)$. The lowest value of urinary $\mathrm{N}$ was in LPG $(19.7$ $\mathrm{g} / \mathrm{d})$ while the highest was in control $(32.9 \mathrm{~g} / \mathrm{d})$. Furthermore, the results revealed a significant increase in $\mathrm{N}$ balance (both absorption and retention) in all herb supplemented treatments $(\mathrm{p}<0.05)$. The highest values of $\mathrm{N}$ absorption and retention were in L treatment; 94.4 and 73.3 $\mathrm{g} / \mathrm{d}$, respectively. There were no differences of allantoin excretion and absorption among treatments $(p>0.05)$. In addition, microbial $\mathrm{N}$ supply (MNS) and efficiency of microbial $\mathrm{N}$ synthesis (EMNS) were not influenced by herb as compared to the control ( $\mathrm{p}>0.05)$.

\section{DISCUSSION}

\section{Chemical composition of feed}

Concentrate mixture was formed using available local feed resources and was well consumed by all animals during the whole experimental periods. Rice straw contained low CP and high non-structural carbohydrate as reported by Wanapat et al. (2009). However, the nutritive value of rice straw had been improved by urea treatment in this study up to $74 \mathrm{~g} / \mathrm{kg}$ DM. Moreover, urea treatment could decrease the proportion of aNDF and ADF content in rice straw to 716 and $526 \mathrm{~g} / \mathrm{kg} \mathrm{DM}$, respectively. These values were similar to those in earlier reports by Wanapat et al. (2009) and Mapato et al. (2010) where 5\% urea treatment was used to improve the nutritive values of rice straw. On the other hand, the mean CP level of $\mathrm{G}$ was the highest among all herbs following by $\mathrm{L}$ and $\mathrm{P}(180,14$ and

Table 4. Influence of lemongrass, peppermint and garlic supplementation on dry matter intake and apparent nutrient digestibility

\begin{tabular}{|c|c|c|c|c|c|c|c|c|}
\hline & \multicolumn{4}{|c|}{ Treatment $(\mathrm{g} / \mathrm{d})^{\mathrm{a}}$} & \multirow{2}{*}{ SEM } & \multicolumn{3}{|c|}{ Contrast $\mathrm{p}$} \\
\hline & $\mathrm{C}$ & $\mathrm{L}$ & LP & LPG & & C vs Sup ${ }^{b}$ & L vs LP, LPG & LP vs LPG \\
\hline \multicolumn{9}{|l|}{ Dry matter intake } \\
\hline \multicolumn{9}{|l|}{ UTRS intake } \\
\hline $\mathrm{kg} / \mathrm{d}$ & 7.3 & 7.3 & 7.5 & 7.1 & 0.06 & 0.41 & 0.12 & 0.13 \\
\hline $\mathrm{g} / \mathrm{kg} \mathrm{BW}^{0.75}$ & 77.8 & 75.8 & 80.0 & 75.5 & 2.05 & 0.78 & 0.55 & 0.15 \\
\hline \multicolumn{9}{|l|}{ Concentrate intake } \\
\hline $\mathrm{kg} / \mathrm{d}$ & 2.1 & 2.2 & 2.1 & 2.2 & 0.06 & 0.98 & 0.67 & 0.26 \\
\hline $\mathrm{g} / \mathrm{kg} \mathrm{BW}^{0.75}$ & 22.7 & 22.9 & 22.7 & 22.8 & 0.15 & 0.95 & 0.68 & 0.26 \\
\hline \multicolumn{9}{|l|}{ Total intake } \\
\hline $\mathrm{kg} / \mathrm{d}$ & 9.4 & 9.5 & 9.6 & 9.3 & 0.35 & 0.23 & 0.15 & 0.12 \\
\hline $\mathrm{g} / \mathrm{kg} \mathrm{BW}^{0.75}$ & 96.8 & 99.9 & 102.2 & 98.1 & 2.14 & 0.54 & 0.12 & 0.19 \\
\hline \multicolumn{9}{|c|}{ Apparent digestibility $(\mathrm{kg} / \mathrm{kg})$} \\
\hline Dry matter & 0.61 & 0.67 & 0.60 & 0.61 & 0.027 & 0.32 & 0.45 & 0.77 \\
\hline Organic matter & 0.74 & 0.72 & 0.63 & 0.65 & 0.024 & 0.15 & 0.39 & 0.83 \\
\hline Crude protein & 0.60 & 0.65 & 0.57 & 0.53 & 0.064 & 0.05 & 0.01 & 0.62 \\
\hline Neutral detergent fibre & 0.65 & 0.69 & 0.59 & 0.56 & 0.013 & 0.17 & 0.37 & 0.85 \\
\hline Acid detergent fibre & 0.54 & 0.57 & 0.54 & 0.53 & 0.002 & 0.14 & 0.35 & 0.67 \\
\hline
\end{tabular}

${ }^{\mathrm{a}} \mathrm{C}=$ Control; $\mathrm{L}=$ Lemongrass meal; LP = Lemongrass meal and peppermint powder; $\mathrm{LPG}=$ Lemongrass meal plus peppermint and garlic powder.

${ }^{\mathrm{b}}$ Supplemented diets. 
Table 5. Effect of herb dietary on $\mathrm{N}$ balance and urinary purine derivatives in cattle

\begin{tabular}{|c|c|c|c|c|c|c|c|c|}
\hline & \multicolumn{4}{|c|}{ Treatment $(\mathrm{g} / \mathrm{d})^{\mathrm{a}}$} & \multirow{2}{*}{ SEM } & \multicolumn{3}{|c|}{ Contrast $\mathrm{p}$} \\
\hline & $\mathrm{C}$ & $\mathrm{L}$ & LP & LPG & & C vs Sup ${ }^{b}$ & L vs LP, LPG & LP vs LPG \\
\hline \multicolumn{9}{|l|}{$\mathrm{N}$ utilization $(\mathrm{g} / \mathrm{d})$} \\
\hline Intake & 133.8 & 136.1 & 136.2 & 133.7 & 4.50 & 0.10 & 0.34 & 0.64 \\
\hline \multicolumn{9}{|l|}{ Excretion } \\
\hline Fecal & 42.4 & 41.7 & 45.7 & 43.8 & 5.14 & 0.18 & 0.87 & 0.95 \\
\hline Urinary & 32.9 & 21.1 & 29.0 & 19.7 & 0.63 & 0.04 & 0.15 & 0.23 \\
\hline \multicolumn{9}{|l|}{ Balance } \\
\hline Absorption & 91.4 & 94.4 & 90.5 & 89.9 & 2.01 & 0.03 & 0.37 & 0.78 \\
\hline Retention & 58.5 & 73.3 & 61.5 & 70.2 & 2.56 & 0.01 & 0.04 & 0.05 \\
\hline \multicolumn{9}{|l|}{ Purine derivative (mmol/d) } \\
\hline Excretion & 167.9 & 162.9 & 159.7 & 159.3 & 7.25 & 0.94 & 0.35 & 0.32 \\
\hline Absorption & 160.9 & 155.0 & 151.3 & 150.8 & 8.18 & 0.17 & 0.39 & 0.33 \\
\hline $\mathrm{MN}$ supply $\left(\mathrm{g} \mathrm{N} / \mathrm{d}^{\mathrm{c}}\right)$ & 117.0 & 112.7 & 110.0 & 109.6 & 2.55 & 0.16 & 0.15 & 0.25 \\
\hline $\operatorname{EMNS}^{\mathrm{d}}(\mathrm{g} \mathrm{N} / \mathrm{kg} \text { OMDR })^{\mathrm{e}}$ & 46.8 & 45.1 & 44.0 & 43.9 & 3.83 & 0.29 & 0.11 & 0.98 \\
\hline
\end{tabular}

${ }^{\mathrm{a}} \mathrm{C}=$ Control; $\mathrm{L}=$ Lemongrass meal; $\mathrm{LP}=$ Lemongrass meal and peppermint powder; LPG = Lemongrass meal plus peppermint and garlic powder.

${ }^{\mathrm{b}}$ Supplemented diets. ${ }^{\mathrm{c}}$ Microbial N supply. ${ }^{\mathrm{d}}$ Efficiency of microbial protein supply (g N/kg OMDR).

${ }^{\mathrm{e}} \mathrm{DOMR}=$ Digestible OM apparently fermented in the rumen (assuming that rumen digestion was $650 \mathrm{~g} / \mathrm{kg} \mathrm{OM}$ of digestion in the total tract, DOMR = DOMI $\times 0.65 ;$ DOMI = Digestible OM intake).

$12 \mathrm{~g} / \mathrm{kg}$ DM, respectively). These values were similar to the report of Wanapat et al. (2008a, b), but the CP of G was slightly lower than the value reported by Kongmun et al. (2010) (229 g/kg), possibly due to the difference between variety and age of the herbs. Meanwhile, both $G$ and $L$ contained a much higher level of aNDF as well as ADF when compared with P. It was similar to those reported by Wanapat et al. (2008a, b) and Kongmun et al. (2010).

\section{Rumen fermentation and blood metabolites}

In the present finding, ruminal $\mathrm{pH}$ tended to be increased in the herb supplemented groups. However, it was in contrast to the finding of Yang et al. (2007) and Wanapat et al. (2008a, b) who reported that ruminal $\mathrm{pH}$ was not affected by garlic powder or lemongrass meal supplementation while other researchers have observed that peppermint supplementation decreased ruminal $\mathrm{pH}$ (Ando et al., 2003; Hosoda et al., 2006). Moreover, this study revealed that $\mathrm{NH}_{3}-\mathrm{N}$ and BUN concentrations were significantly decreased by herb supplementation, which was consistent with the finding of Ando et al. (2003) and Busquet et al. (2006). However, ruminal $\mathrm{NH}_{3}-\mathrm{N}$ concentrations in the present study were in normal range as reported by Wanapat and Pimpa (1999). Supplementation with lemongrass and garlic powder decreased ruminal $\mathrm{NH}_{3}-$ $\mathrm{N}$ and plasma urea $\mathrm{N}$ in the study of Wanapat et al. (2008a, b). Similarly, supplementation of essential oil from peppermint herb or high essential oil at $3,000 \mathrm{mg} / \mathrm{L}$ significantly decreased $\mathrm{NH}_{3}-\mathrm{N}$ concentration (Ando et al., 2003; Busquet et al., 2006). Ruminal $\mathrm{NH}_{3}-\mathrm{N}$ is a major source of $\mathrm{N}$ for microbial protein synthesis (Bryant, 1974; Erdman et al., 1986). Moreover, decreasing rumen $\mathrm{NH}_{3}-\mathrm{N}$ concentrations also resulted in decreasing concentrations of plasma urea $\mathrm{N}$. Concentrations of plasma urea $\mathrm{N}$ are highly correlated with the concentration of $\mathrm{NH}_{3}$ production in the rumen (Preston et al., 1965; Lewis, 1957). It could be due to the effect of essential oil contained in each herb used in this study, which affected microbial growth and fermentation. Therefore, in the present result the proteolytic bacterial number was decreased with herb treatments. There is considerable evidence that essential oils may affect rumen microbial fermentation (McIntosh et al., 2000; McEwan et al., 2002). Wallace et al. (2002) suggested that the main mechanism of action of essential oils was the inhibition of bacterial attachment to feed particles, and subsequently, $\mathrm{NH}_{3}$ production (deamination) from AA decreased. This effect was mediated by the effects of essential oils particularly on hyper- $\mathrm{NH}_{3}$-producing bacteria. McEwan et al. (2002) reported that addition of essential oils resulted in a reduction in the number and diversity of hyper- $\mathrm{NH}_{3}-$ producing bacteria, resulting in decreased rate of $\mathrm{NH}_{3}$ production from AA. Reduction in protein degradation suggests that at least a part of the effects of essential oils can be attributed to decreased proteolysis (Molero et al., 2004). A decrease in ruminal $\mathrm{NH}_{3}-\mathrm{N}$ and BUN could provide ruminal by-pass protein as an alteration effect of rumen deamination (Wallace et al., 1994; Newbold et al., 2004; Cardozo et al., 2005). Generally, when proteins can be protected from ruminal deamination, ammonia declines and ruminants would have more amino acids available in the lower gut. Moreover, this agrees with the finding of Cardozo et al. (2004) who reported that garlic oil used in continuous culture reduced $\mathrm{NH}_{3}-\mathrm{N}$, but increased peptide and amino acid $\mathrm{N}$ concentrations which suggested that the deamination was inhibited.

The results in this study did not show any significant 
difference in total VFA and $\mathrm{C} 4$ concentration while $\mathrm{C} 2$ was decreased and C3 was increased by herb supplementation. Similar to the present result, Wanapat et al. (2008b) found that the use of $\mathrm{G}$ alone as a supplement did not affect total VFA, but increased C3 concentration. Moreover, Ando et al. (2003), Hosoda et al. (2006) and Wanapat et al. (2008a) also reported that supplementation of $\mathrm{L}$ in the diets did not change the VFA concentration. This was also supported by the finding of Busquet et al. (2005) who have shown that garlic oil supplementation decreased $\mathrm{C} 2$, but increased $\mathrm{C} 3$ as found in the present study. In the present study, the total bacterial population was changed by herb supplement without an affect on total VFA production. This could be due to many essential oils having dose-dependent effects on bacteria, protozoa, and fungi (Greathead, 2003). However, gram-positive bacteria appeared to be more susceptible to inhibition by plant essential oil compounds than did gramnegative bacteria (Davidson and Naidu, 2000). Therefore, there was no effect on fiber digestion due to the gramnegative bacteria playing the major role in fiber digestion. This means there was no effect on VFA production by herb supplementation. The lack of an effect of essential oils has been related to the presence of an outer membrane on gramnegative organisms, which endows them with a hydrophilic surface that acts as a strong impermeability barrier (Nikaido, 1994). Meanwhile, Hosoda et al. (2006) reported the same result as the present finding that supplementation of peppermint in early lactating dairy cows had no effect on TVFA. On the other hand, herb supplementation reduced $\mathrm{CH}_{4}$ and this was similar to the finding of Kongmun et al. (2010). Moreover, Agarwal et al. (2009) also found that rumen $\mathrm{CH}_{4}$ was reduced in a peppermint oil supplemented group. According to Ørskov et al. (1991), the shift in ruminal VFAs and reduction of $\mathrm{CH}_{4}$ would improve rumen fermentation efficiency especially energy economy in the host ruminants.

\section{Rumen microorganism population}

In the present result, ruminal protozoa and bacterial populations were decreased by herb supplementation while fungal zoospores were not affected. These findings were consistent with the work of Wanapat et al. (2008a) who found that ruminal microbial and total viable count were decreased by the high level of lemongrass supplementation. This may be due to the effects of essential oil from herbs, which changed the diversity of rumen microorganism. Many essential oils have dose-dependent effects on bacteria, protozoa, and fungi (Greathead, 2003). The correlation between plant extract and protozoa number might be explained by the low capability of permeable properties of their cell membrane. Using peppermint oil or garlic powder diets, Agarwal et al. (2009) and Kongmun et al. (2010) reported that the numbers of protozoa were reduced while cellulolytic bacteria increased. Wanapat et al. (2008b) also reported the same result with garlic powder supplementation which tended to decrease the protozoal and bacterial populations, while the fungal zoospore population was not affected. The activity of herbs affects electron transport, ion gradients, protein translocation, phosphorylation steps, and other enzyme-dependent reactions, causing the affected bacteria to lose chemiosmotic control (Ultee et al., 1999). In our study, supplementation of herbs decreased bacterial populations, possibly due to decreases of gram-positive bacteria.

Moreover, herb additives had an effect on viable total bacterial counts and proteolytic bacteria in this study. The reduction of proteolytic bacteria in L, LP or LPG supplementation groups was correlated with a lower ruminal $\mathrm{NH}_{3}-\mathrm{N}$ concentration. However, the herb additive showed no effect on the populations of cellulolytic and amylolytic bacteria. Therefore, the present result showed no effect on VFA production and digestibility, especially fiber digestion. Similarly, Wallace et al. (2002) reported that hyper-NH3-producing bacteria as proteolytic bacteria group were the most sensitive of rumen bacteria to essential oil in pure culture. Protozoal populations were decreased with herb supplementation in the diets especially in herb combination group. In agreement with these observations, Ando et al. (2003) reported that supplementation of essential oil from peppermint decreased protozoal population significantly.

\section{Feed intake and apparent digestibility of nutrients}

Herb supplementation had no effect on DMI and nutrient digestibility, except $\mathrm{CP}$, in the present study. This agrees with Benchaar et al. (2007) and Yang et al. (2007) who found no change in DMI when dairy cows were fed with the mixture of essential oil compounds or garlic oil. In addition, Wanapat et al. (2008a, b) found that G and/or L supplementation did not affect DMI of beef cattle as compared to a control group. Similarly, Benchaar et al. (2007) and Hosoda et al. (2006) also support the present finding with their studies that showed DMI did not change with mixtures of essential oil compounds supplemented at $750 \mathrm{mg} / \mathrm{d}$ in dairy cows and lemongrass leaf in dairy steers, respectively. In contrast, Cardozo et al. (2005) found that the combination of cinnamaldehyde at $18 \mathrm{mg} / \mathrm{d}$ and eugenol at $90 \mathrm{mg} / \mathrm{d}$ reduced total DMI in beef cattle. This contrast to the present study may be due to the use of herb supplementation in the powder and oil form and the concentration of the compound.

The present results of no change of nutrient digestibility were consistent with the previous findings of Castillejos et al. (2006), Hosoda et al. (2006) and Wanapat et al. (2008a, b) which reported that nutrient digestibility did not change when animals were supplemented with plant herbs. 
According to Busquet et al. (2005), true digestibility of DM, OM, aNDF and ADF were not affected by garlic oil supplementation. On the other hand, Ando et al. (2003) reported that supplementation with peppermint could increase nutrient digestibility which contrasts with the present findings. In addition, the work of Yang et al. (2007) showed that feeding garlic oil to dairy cattle could increase ruminal DM and OM digestibility and Kongmun et al. (2010) showed that garlic powder supplementation at 16 $\mathrm{mg} / \mathrm{d}$ did affect in vitro true digestibility. In the present finings, apparent digestibility of CP tended to decrease in the herb supplemented animals and this was in the agreement with earlier observations which showed that supplementations of lemongrass or garlic powder could decrease CP digestibility (Wanapat et al., 2008a, b).

\section{Nitrogen utilization and purine derivatives}

The total $\mathrm{N}$ intake and fecal $\mathrm{N}$ excretion were found to be similar in all treatments, but urinary $\mathrm{N}$ excretion was decreased in animals supplemented with herbs, especially in the LPG treatment. Wanapat et al. (2008b) reported a result similar to the present study in that there was no effect of herb supplementation on $\mathrm{N}$ intake as well as $\mathrm{N}$ excretion. This was consistent with Kearl (1982) that endogenous loss from the digestive tract may not be different in each animal; therefore, fecal $\mathrm{N}$ in each animal was similar as all animals were fed the same amount diet. Moreover, it was observed that positive $\mathrm{N}$ retention and absorption were obtained in the herb supplemented treatments (Wanapat et al., 2008a; b) which supports the present result of increasing $\mathrm{N}$ absorption and retention in herb treatments, especially $\mathrm{L}$ treatment. With regards to $\mathrm{N}$ utilization, Owens and Zinn (1988) stated that $\mathrm{N}$ excretion and retention should reflect the differences in $\mathrm{N}$ metabolism due to $\mathrm{N}$ retention being the most important index of the protein nutrition status of ruminants. In contrast to the present result, Wanapat et al. (2008a) reported that $\mathrm{N}$ utilization in $\mathrm{L}$ supplemented and control treatments were not different from each other. This was possibly due to the dose level of supplementation. It has been reported that $\mathrm{N}$ excretion through urine was increased due to CP diet and $\mathrm{N}$ intake (Mehra et al., 2006; Pimpa et al., 2009) as well as a high RDP ratio in the dietary protein (Javaid et al., 2008). Normally, when protein degradation is more rapid than synthesis, ammonia will accumulate in the rumen liquor and is absorbed into the blood then carried to the liver where it is converted to urea and excreted via urine N (Mcdonald et al., 1995).

Meanwhile, herb supplementation did not effect allantoin excretion and absorption, MNS and EMNS in the present study. These absorptions were in agreement with Yang et al. (2007) who reported that garlic supplementation in lactating dairy cows had no effect on purine derivatives. The amount of MNS flow from the rumen is a consequence of microbial growth (Weisbjerg et al., 1996) and is an indicator of the rumen nitrogen efficiency. Microbial protein synthesis in the rumen provides the majority of protein supplied to the small intestine of ruminants, accounting for 50 to $80 \%$ of total absorbable protein (Firkins et al., 2007). The sensitivity of protozoa towards essential oils may be explained by the presence of sterols in their cell membranes (Greathead, 2003). The present result of no effect on purine derivatives is in accord with observations that bacterial populations in roll-tube experiments are not affected by herb supplements. The present data, however, was in contrast with the results of Wanapat et al. (2008a) who found lower EMNS in beef cattle supplemented with lemongrass. The type of herb and level of supplementation may have attributed to the variability of results on EMNS and urinary purine derivatives, respectively. However, Wanapat et al. (2008b) showed a similar result to the present finding that garlic supplementation did not produce any significant changes in microbial protein synthesis and/or urinary purine derivatives.

\section{CONCLUSIONS AND RECOMMENDATIONS}

Based on this study, it could be concluded that lemongrass and/or in combination with peppermint and garlic powder as rumen additives showed no negative effect of ruminal fermentation characteristics and nutrient utilization. Moreover, lemongrass and/or in combination could decrease protozoal population and methane production and especially increase propionate and $\mathrm{N}$ utilization. Therefore, lemongrass and/or combination of peppermint and garlic powder could be used as a rumen additive feed for rumen ecology enhancement.

\section{ACKNOWLEDGEMENTS}

The authors express their most sincere gratitude and appreciation to the Tropical Feed Resources Research and Development Center (TROFREC) for financial support of the research and use of research facilities, and all animal science graduate students for their assistance with the animal experiment and sample chemical analyses.

\section{REFERENCES}

Agarwal, N., C. Shekhar, R. Kumar, L. C. Chaudhary, and D. N. Kamra. 2009. Effect of peppermint (Mentha piperita) oil on in vitro methanogenesis and fermentation of feed with buffalo rumen liquor. Anim. Feed Sci. Technol. 148:321-327.

Ando, S., T. Nishida, M. Ishida, K. Hosoda, and E. Bayaru. 2003. Effect of peppermint feeding on the digestibility, ruminal fermentation and protozoa. Livest. Prod. Sci. 82:245-248.

AOAC. 1995. Official method of analysis, 16th ed. Animal Feeds: 
Association of Official Analytical Chemists, Arlington, VA, USA. pp. 1-18.

Bampidis, V. A., V. Christodoulou, E. Christaki, P. Florou-Paneri, and A. B. Spais. 2005. Effect of dietary garlic bulb and garlic husk supplementation on performance and carcass characteristics of growing lambs. Anim. Feed Sci. Technol. 121:273-283.

Benchaar, C., H. V. Petit, R. Berthiaume, D. R. Ouellet, J. Chiquette, and P. Y. Chouinard. 2007. Effects of essential oils on digestion, ruminal fermentation, rumen microbial populations, milk production, and milk composition in dairy cows fed alfalfa silage or corn silage. J. Dairy Sci. 90:886-897.

Bryant, M. P. 1974. Nutritional features and ecology of predominant anaerobic bacteria of the intestinal tract. Am. J. Clin. Nutr. 27:1313-1319.

Busquet, M., S. Calsamiglia, A. Ferret, and C. Kamel. 2006. Plant extracts affect in vitro rumen microbial fermentation. J. Dairy Sci. 89:761-771.

Busquet, M., S. Calsamiglia, A. Ferret, M. D. Carro, and C. Kamel. 2005. Effect of garlic oil and four of its compounds on rumen microbial fermentation. J. Dairy Sci. 88:4393-4404.

Cardozo, P. W., S. Calsamiglia, A. Ferret, and C. Kamel. 2004. Effects of natural plant extracts on ruminal protein degradation and fermentation profiles in continuous culture. J. Anim. Sci. 82:3230-3236.

Cardozo, P. W., S. Calsamiglia, A. Ferret, and C. Kamel. 2005. Screening for the effects of natural plant extracts at different $\mathrm{pH}$ on in vitro rumen microbial fermentation of a highconcentrate diet for beef cattle. J. Anim. Sci. 83:2572-2579.

Castillejos, L., S. Calsamiglia, and A. Ferret. 2006. Effect of essential oil active compounds on rumen microbial fermentation and nutrient flow in in vitro systems. J. Dairy Sci. 89:2649-2658.

Chen, X. B., and M. J. Gomes. 1995. Estimation of microbial protein supply to sheep and cattle based on urinary excretion of purine derivative- an overview of the technique details. Occasional publication, 1992. International feed resources unit, Rowett Research Institute, Aberdeen, UK.

Chen, X. B., D. J. Kyle, and E. R. Ørskov. 1993. Measurement of allantoin in urine and plasma by high-performance liquid chromatography with pre-column derivatization. J. Chromatogr. 617:241-247.

Chi, M. S., E. T. Koh, and T. J. Steward. 1982. Effects of garlic on lipid metabolism in rats fed cholesterol or lard. J. Nutr. 112: 241-248.

Crocker, C. L. 1967. Rapid determination of urea nitrogen in serum or plasma without deproteinization. Am. J. Med. Technol. 33:361-365.

Davidson, P. M., and A. S. Naidu. 2000. Phyto-phenols. Pages 265-293 in Natural Food Antimicrobial Systems. A. S. Naidu, ed. CRC Press, Boca Raton, FL, USA.

Erdman, R. A., G. H. Proctor, and J. H. Vandersall. 1986. Effect of rumen ammonia concentration on in situ rate and extent of digestion of feedstuffs. J. Dairy Sci. 69:2312-2320.

Firkins, J. L., Z. Yu, and M. Morrison. 2007. Ruminal nitrogen metabolism: perspectives for integration of microbiology and nutrition for dairy. J. Dairy Sci. 90 (E. Suppl.):E1-E16.

Galyean, M. 1989. Laboratory procedure in animal nutrition research, Department of Animal and Range Sciences, New
Mexico State University, Cig, NY, USA.

Greathead, H. 2003. Plant and plant extracts for improving animal productivity. Proc. Nutr. Soc. 62:279-290.

Hobson, P. N. 1969. Continuous culture of some anaerobic and facutatively anaerobic rumen bacteria. J. Gen. Microbiol. 38: $80-167$.

Hosoda, K., H. Matsuyama, W. Y. Park, T. Nishida, and M. Ishida. 2006. Supplementary effect of peppermint (Menthaxpiperita) on dry matter intake, digestibility, ruminal fermentation and milk production in early lactating dairy cows. Anim. Sci. J. 77: 503-509.

Hosoda, K., T. Nishida, W. Y. Park, and B. Eruden. 2005. Influence of Mentha piperita L. (peppermint) supplementation on nutrient digestibility and energy metabolism in lactating dairy cows. Asian-Aust. J. Anim. Sci. 18:1721-1726.

Hungate, R. E. 1969. A roll tube method for cultivation of strict anaerobes. In: Method in Microbiology (Ed. J. R. Norris, and D. W. Ribbons). Academic Publishers, New York, NY, USA, pp. 313.

Javaid, A., M. Mahr-un-Nisa, M. Sarwar, and M. A. Shahzad. 2008. Ruminal characteristics, blood $\mathrm{pH}$, blood urea nitrogen and nitrogen balance in Nili ravi buffalo (Bubalus bulalis) bulls fed diets containing various levels of ruminally degradable protein. Asian-Aust. J. Anim. Sci. 21:51-58.

Kearl, L. C. 1982. Nutrient requirements of ruminants in developing countries, 1st ed. International Feedstuffs Institute, Utah State University, Logan, Utah, USA.

Kongmun, P., M. Wanapat, P. Pakdee, and C. Navanukraw. 2010. Effect of coconut oil and garlic powder on in vitro fermentation using gas production technique. Livest. Sci. 127:38-44.

Kongmun, P., M. Wanapat, P. Pakdee, C. Navanukraw, and Z. Yu. 2011. Manipulation of rumen fermentation and ecology of swamp buffalo by coconut oil and garlic powder supplementation. Livest. Sci. 135:84-92.

Lewis, D. 1957. Blood urea concentration in relation to protein utilization in the ruminant. J. Agric. Sci. (Camb.) 48:438-446.

Mapato, C., M. Wanapat, and A. Cherdthong. 2010. Effect of urea treatment of straw and dietary level of vegetable oil on lactating dairy cows. Trop. Anim. Health Prod. 42:1635-1642.

Mcdonald, P., R. A. Edwards, J. E. D. Greenhalgh, and C. A. Morgan. 1995. In: Animal Nutrition 5th ed. Perntice Hall, USA, p. 693.

McEwan, N. R., R. C. Graham, R. J. Wallace, R. Losa, P. Williams, and C. J. Newbold. 2002. Effect of essential oils on ammonia production by rumen microbes. Reprod. Nutr. Dev. 42(Suppl.1):S65. (Abstr.)

McGuffey, R. K., L. F. Richardson, and J. I. D. Wilkinson. 2001. Ionophore for dairy cattle: current status and future outlook. J. Dairy Sci. 84:E194-E203.

McIntosh, F. M., C. J. Newbold, R. Losa, P. Williams, and R. J. Wallace. 2000. Effects of essential oils on rumen fermentation. Reprod. Nutr. Dev. 40:221-222. (Abstr.)

Mehra, U. R., M. Y. Khan, M. Lal, Q. Z. Hasan, and A. Das. 2006. Effect of sources of supplementary protein on intake, digestion and efficiency of energy utilization in buffalos fed wheat straw based diets. Asian-Aust. J. Anim. Sci. 19:638-644.

Molero, R., M. Ibars, S. Calsamiglia, A. Ferret, and R. Losa. 2004. Effects of a specific blend of essential oil compounds on dry 
matter and crude protein degradability in heifers fed diets with different forage to concentrate ratios. Anim. Feed Sci. Technol. 114:91-104.

Moss, A. R., J. P. Jouany, and J. Newbold. 2000. Methane production by ruminants: its contribution to global warming. J. Ann. Zootech. 49:231-253.

Newbold, C. J., F. M. McIntosh, P. Williams, R. Losa, and R. J. Wallace. 2004. Effects of a specific blend of essential oil compounds on rumen fermentation. Anim. Feed Sci. Technol. 114:105-112.

Nikaido, H. 1994. Prevention of drug access to bacterial targets: Permeability barriers and active efflux. Science 264:382-388.

Ørskov, E. R., N. A. MacLeod, and Y. Nakashima. 1991. Effect of different volatile fatty acids mixtures on energy metabolism in cattle. J. Anim. Sci. 69:3389-3397.

Owens, F. N., and R. Zinn. 1988. Protein metabolism of ruminant animals. Pages 227-249 in The Ruminant Animal Digestive Physiology and Nutrition. D. C. Church, ed. Waveland Press Inc., Prospect Heights, IL.

Patra, A. K., D. N. Kamra, and N. Agarwal. 2006. Effect of spices on rumen fermentation, methanogenesis and protozoa counts in in vitro gas production test. Int. Congr. Ser. 1293:176-179.

Pimpa, O., S. Ruengsuwan, and B. Pimpa. 2009. Protein requirements for maintenance and growing of Thai southern native cattle: practical feeding trial on farm of South-Thailand. In: Establishment of a Feeding Standard of Beef Cattle and a Feed Database for the Indochiness Peninsula (Ed. S. Oshio, M. Otsuka, and K. Sommart). JIRCAS, Tsukuba, Ibaraki, Japan, pp. 86-89.

Preston, R. L., D. D. Schnakanberg, and W. H. Pfander. 1965. Protein utilization in ruminants. I. Blood urea nitrogen as affected by protein intake. J. Nutr. 86:281-288.

Russell, J. B., and A. J. Houlihan. 2003. Ionophore resistance of ruminal bacteria and its potential impact on human health. FEMS Microbiol. Rev. 27:65-74.

Samuel, M., S. Sagathewan, J. Thomas, and G. Mathen. 1997. An HPLC method for estimation of volatile fatty acids of ruminal fluid. Indian J. Anim. Sci. 67:805-811.

SAS. 1996. User's Guide: Statistic, Version 6. 12th Edition. SAS Inst. Inc., Cary, NC, USA.

Shin, S. H. and M. K. Kim. 2004. Effect of dried powders or ethanol extracts of garlic flesh and peel on lipid metabolism and antithrombogenic capacity in 16 -month-old rats. Korean J. Nutr. 37:515-524.
Tatara, M. R., E. Sliwa, K. Dudek, A. Gawron, and T. Piersiak. 2008. Aged garlic extract and allicin improve performance and gastrointestinal tract development of piglets reared in artificial sow. Ann. Agric. Environ. Med. 15:63-69.

Ultee, A., E. P. W. Kets, and E. J. Smid. 1999. Mechanism of action of carvacrol on the food-borne pathogen Bacillus cereus. Appl. Environ. Microbiol. 65:4606-4610.

Van Soest, P. J., J. B. Robertson, and B. A. Lewis.1991. Methods of dietary fiber, neutral detergent fiber and non-starch carbohydrates in relation to animal nutrition. J. Dairy Sci. 74: 3583-3597.

Wallace, R. J., L. Athaud, and C. J. Newbold. 1994. Influence of Yucca shidigera extract on rumen ammonia concentrations and ruminal microorganisms. Appl. Environ. Microbiol. 60:17621767.

Wallace, R. J., N. R. McEwan, F. M. McIntosh, B. Teferedegne, and C. J. Newbold. 2002. Natural products as manipulators of rumen fermentation. Asian-Aust. J. Anim. Sci. 15:1458-1468.

Wanapat, M., and O. Pimpa. 1999. Effect of ruminant $\mathrm{NH}_{3}-\mathrm{N}$ levels on ruminal fermentation, purine derivative, digestibility and rice straw intake in swamp buffalo. Asian-Aus. J. Anim. Sci. 12:904-907.

Wanapat, M., A. Cherdthong, P. Pakdee, and S. Wanapat. 2008a. Manipulation of rumen ecology by dietary lemongrass (Cymbopogon citratus Stapf) powder supplementation. J. Anim. Sci. 86:3497-3503.

Wanapat, M., P. Khejornsart, P. Parkdee, and S. Wanapat. 2008b. Effect of supplementation of garlic powder on rumen ecology and digestibility of nutrients in ruminants. J. Sci. Food Agric. 88:2231-2237.

Wanapat, M., S. Polyorach, K. Boonnop, C. Mapato and A. Cherdthong. 2009. Effects of treating rice straw with urea or urea and calcium hydroxide upon intake, digestibility, rumen fermentation and milk yield of dairy cows. Livest. Sci. 125: 238-243.

Weisbjerg, M. R., T. Hvelplund, S. Hellberg, S. Olsson, and S. Same. 1996. Effective rumen degradability and intestinal digestibility of individual amino acids in different concentrates determined in situ. Anim. Feed Sci. Technol. 62:179-188.

Yang, W. Z., C. Benchaar, B. N. Ametaj, A. V. Chaves, M. L. He, and T. A. McAllister. 2007. Effects of garlic and juniper berry essential oils on ruminal fermentation, site and extent of digestion in lactating cows. J. Dairy Sci. 90:5671-5681. 